\title{
The Influence of Learning Method Make a Match on the Mastery of Chinese Language Vocabulary of the Pupils at Dr. Wahidin Sudirohusodo Primary School
}

\author{
Eddy Harianto ${ }^{1, *}$, Jimmy Thomas ${ }^{2}$ \\ ${ }^{1}$ Educational Technology Graduate Program, State University of Medan, Medan, Indonesia \\ ${ }^{2}$ Chinese Literature Study Program, STBA-PIA, Medan, Indonesia \\ ${ }^{*}$ Corresponding author. Email: eddycji2@gmail.com
}

\begin{abstract}
This study aims to know how much the influence of cooperative learning method "Make a match" on the mastery of Chinese language vocabulary of the pupils at Dr. Wahidin Sudirohusodo primary school. This study uses quantitative research method, a type of quasi experimental design, with pre-test and post-test. The research sample consisted of 40 pupils for the experimental class and another 40 pupils for the control class. The hypothesis proposed of this study is that there is a significant influence on the mastery of Chinese language vocabulary. The data is collected through pretest, post-test, and learning outcomes test instrument from the book of Chinese language "lai xue xi hua wen". The result of the uncorrelated sample t-test showed that the cooperative learning method "Make a match" had a significant influence on the mastery of Chinese language vocabulary. Data analysis using t-test shows the result of the experimental class post-test learning is 89,00 while the control class is 64,75 . Thus the cooperative learning method "Make a match" has a significant influence on the mastery of Chinese language vocabulary of the pupils at Dr. Wahidin Sudirohusodo primary school.
\end{abstract}

Keywords: Make A Match, Mastery of Vocabulary, Chinese Language

\section{INTRODUCTION}

Learning is a process of interaction between teachers and learners with learning resources in a learning environment that includes teachers and pupils exchange information. Learning is an effort or activity that is done so knowingly know or can find out something [1]. The results of learning activities is self-change, from a state of not knowing becomes know, from not doing anything into doing something.

Learning method is the way that teachers used to convey lessons to the learners [2]. Learning method is the way that teachers used in making interaction with the learners at the time of teaching [3]. There are several learning methods teachers used that can be divided into direct-based learning methods, cooperative learning methods, problem-based learning methods, and contextual learning methods [4].

One of the methods that is commonly used is cooperative learning methods. Cooperative learning is a type of learning methods where the pupils learn and do activities in collaborative in small groups of four to six members with the structure of the group is heterogeneous [5]. Cooperative learning is learning strategies which include the participation of the pupils in a small group for interacting [6]. Thus, the cooperative learning is a method of learning in which pupils are invited to participate or cooperate in small group of learning situation.

In learning activities, a teacher should understand the learning method they used and customize it in teaching of a class. However, most teachers at Dr. Wahidin Sudirohusodo Primary School still use lectures method in teaching language class. That makes the pupils become bored during the class and the results of the learning are not good. From 125 pupils in grade 4 who taking part on monthly assessment, there are only 10 pupils got 100 marks and 27 pupils got the lowest mark of 20. Pupils only recite the subject matter without understanding them. 
In this study we use the cooperative learning methods where pupils are suggested to interact with their classmates in learning Chinese language vocabulary. One of the cooperative learning methods used in this study is Make A Match learning method that uses cards as learning media to seek mates and a method which allows learners to be able to discuss and work together.

This learning method Make A Match is expected to get the attention of the pupils so that they become interested and enthusiastic in learning so as to increase the confidence and good learning results.

\section{THEORETICAL FRAMEWORK}

\subsection{Learning}

Learning can be defined as systematic and deliberate efforts to create educational interaction activities between pupils (learners) and teachers (learning resources) in a learning environment [3]. Learning is aspects of a complex human activity, that cannot be explained [7]. Learning is simply defined as the product of interaction between sustainable development and life experience. Learning in the meaning of the complex is a conscious effort of a teacher to get the pupils learn in order to achieve the learning goals. Based on the definitions above, learning can be defined as the process of learning and teaching in which the teacher provides an effective study program to make the pupils get learning experience in achieving the goals.

\subsection{Make A Match Learning Method}

The cooperative learning method is a learning model that is widely used and is of concern as well as recommended by experts of educators [5]. This is in accordance with the results of the research conducted by Slavin (1995) that the use of cooperative learning method can improve the pupils learning and achievement while enhancing social relationships, fostering attitudes of tolerance, and respect for the opinions of others.

Cooperative learning is a learning activity that uses the pattern of clusters of students learning to establish cooperation and interdependence in the structure of the task, purpose and rewards [8]. The students work together in cooperative learning situations are encouraged to work together on a shared task and they had to coordinate their efforts to complete that task.

There are several types of cooperative learning methods, although the basic principles of this method do not change: Student Teams Achievement Division (STAD), jigsaw, group investigation, make a match, structural model, and Teams Games Tournament (TGT).

Make A Match was first developed by Lorna Curran in 1994 [9]. The purpose of this method is to study the material, excavation material, and edutainment. Make A Match is one of alternatives that can be applied to students, starting from asking the students looking for a pair of cards which is the answer or question before the time limit and then students who obtain cards will be given points. One of the advantages of this technique is the student looking for a spouse while learning about a concept or topic in a fun atmosphere of learning.

Make A Match is method of learning where teachers prepare some cards that contain questions or problems and prepare the answers then students looking for the partner cards [10]. Make A Match can give the opportunity to students to cooperate with others [11]. Make A Match is also a learning system that prioritizes the social ability cultivation of the ability to work together, especially the ability to interact and the ability to have critical think through a game looking for couples with assisted cards [12].

\subsection{Learning Step of Make A Match}

Teachers must do some preparations before applying Make A Match in a class, they are: (1) make some questions related to the subject matter and then write them on the question cards, (2) list the answer keys from the questions before and write them on the answer cards, (3) create rules that contain awards for students who successfully answered and the penalties for students who failed to answer, and (4) provide a sheet to record pairs that successfully while scoring the presentation [9].

The steps of learning Make A Match by [9] are: (1) teacher delivers the lessons or gives assignment to students to study the lessons at home, (2) students are divided into two group and asked to face each other, (3) teacher distributes the question cards to the first group and the answer cards for the second group, (4) teacher instructs the students to find the pair of the card they have with the card from the other group in a time limit, (5) teacher asks the students to find their own pair and report to the teacher to be scored, (6) after the time limit, students who have not find the pair must gather in a group, (7) teacher asks a pair of students to present the cards while the other students give response about the pair of cards, (8) teacher lastly confirms the answer about the presentation, and (9) let the next pair of students to present their pair of cards and so on.

\subsection{Words and Kind of Words}

Word is the smallest part of a language that has meaning and can stand on its own [13]. Words as an important element or basic of structuring sentence have their respective functions in that sentence. Words in Chinese language can be classified into two parts, plus the word affixes like prefixes and suffixes [14]. The kinds of words are: (1) concrete words such as nouns, verbs, adjectives, pronouns, (2) particles such as adverbs, prepositions, conjunctions, and, (3) affixes such as prefixes and suffixes. 


\section{RESEARCH METHOD}

\subsection{Research Design}

This research is a quantitative research using an experimental approach with quasi experimental design, where there are two groups, each of which is chosen randomly. The first group was treated and the other group did not. The treated group was called as the experimental group while the group not treated was called as the control group. After being treated, the subject will be given a post-test. The post-test given is to see the learning outcomes of the subject after being treated and compared with the subject not being treated. The difference in posttest results between the experimental group and the control group shows the results of the treatment given.

\subsection{Population and Sample}

The population of this research is students of grade 4 at Dr. Wahidin Sudirohusodo Primary School in total of 128 pupils which is divided into three classes. Due to the large number of populations in this research, the simple random sampling is used by choosing two classes in total of 80 pupils as the sample of this research, consisted of 40 pupils for the experimental class and another 40 pupils for the control class.

\subsection{Research Instrument}

The instrument for this research is a test instrument. The number of test used is 20 questions that uses matching test type where students will be given a test containing questions and answers placed in two ways: the left lane in the form of questions and right lane in the form of answers. Matching test can make it easier for students to answer the questions because answers are already available, besides that it can train students' memory, easy assessment, objective and can be trusted.

\subsection{Data Collection Procedures}

The data in this research is collected by doing several steps: (1) pre-test, (2) treatment, and (3) post-test. The pre-test is a given test to students before getting treatment to find out the students' intake. The treatment here is a learning process to get the learning outcomes to be achieved. In control class, the lectures method is applied while in experimental class, the Make A Match method is applied. After the learning activities, a final test will be conducted to measure the success of learning.

\subsection{Validity Test}

Validity is a measure that shows the level of validity of an instrument [15]. An instrument is said to be valid if the instrument can be used to measure what should be measured. There are several types of validity, namely construct validity, content validity, and external validity. In this research, content validity is used to compare the contents of the instrument with the subject matter that has been taught. Technically, testing content validity can be helped by using the instrument grid or instrument development matrix.

\subsection{Reliability Test}

Reliability is a measure that shows a level of trust instruments [15]. Reliability test is done for the accuracy of the results obtained from a measurement. In this research, the reliability test will use the formula of Kuder Richardson that is known as K-R 20:

$\mathrm{K}-\mathrm{R} 20=\left(\frac{\mathrm{n}}{\mathrm{n}-1}\right)\left(\frac{\mathrm{s}^{2}-\sum \mathrm{pq}}{\mathrm{s}^{2}}\right)$

Description:

K-R 20 : the overall test reliability

: the proportion of subject with correct answer

q

: the proportion of subject with incorrect answer $(q=1-p)$

$\sum \mathrm{pq} \quad$ : the product of $\mathrm{p}$ and $\mathrm{q} \mathrm{n}$ : number of items

$\mathrm{s}^{2} \quad$ : variance

The calculation result of K-R 20 shows a value above 0.80 , then the instrument test results of the study have a very strong correlation level. The score is used to specify the reference coefficients of correlation as shown as Table 1 below:

\subsection{Data Analysis}

Technique of data analysis in quantitative research using statistics [17]. This analysis is usually divided into two groups, the descriptive statistics and inferential statistics. The data analysis techniques used in this research is descriptive statistics using the mode, median, and mean. As for analyzing the data is done with the T-test.

Table 1. The reference of correlation coefficient interpretation

\begin{tabular}{|c|c|}
\hline Interval Coefficient & Level of Relationship \\
\hline $0.00-0.199$ & Very Low/No relationship \\
\hline $0.20-0.399$ & Low \\
\hline $0.40-0.599$ & Average \\
\hline $0.60-0.799$ & Strong \\
\hline $0.80-1.00$ & Very Strong \\
\hline
\end{tabular}

\section{RESULTS AND DISCUSSION}

Based on the results of the study after learning process using lectures methods, obtained the following 
data where the highest mark is 95 and the lowest mark is 50 with the mean of 64.75 .

Table 2. Frequency Distribution of learning outcomes of control class

\begin{tabular}{|c|c|c|c|}
\hline No. & Interval & Frequency & $\begin{array}{c}\text { Relative } \\
\text { Frequency }\end{array}$ \\
\hline 1 & $50-58$ & 11 & 27.5 \\
\hline 2 & $59-66$ & 15 & 37.5 \\
\hline 3 & $67-74$ & 6 & 15 \\
\hline 4 & $75-82$ & 7 & 17.5 \\
\hline 5 & $83-90$ & 0 & 0 \\
\hline 6 & $91-98$ & 1 & 2.5 \\
\hline \multicolumn{2}{|c|}{ Total } & 40 & $100 \%$ \\
\hline
\end{tabular}

The frequency distribution of learning outcomes shows that most of the pupils who got post-test result between mark of 75 and 98 is 8 pupils, while there are 32 pupils who got the post-test result between mark of 50 and 74.

The results of the study after learning process using Make A Match method, obtained the following data where the highest mark is 100 and the lowest mark is 70 with the mean of 89.00 .

Table 3. Frequency distribution of learning outcomes of experimental class

\begin{tabular}{|c|c|c|c|}
\hline No. & Interval & Frequency & $\begin{array}{l}\text { Relative } \\
\text { Frequency }\end{array}$ \\
\hline 1 & $70-75$ & 3 & 7.5 \\
\hline 2 & $76-80$ & 5 & 12.5 \\
\hline 3 & $81-85$ & 9 & 22.5 \\
\hline 4 & $86-90$ & 10 & 25 \\
\hline 5 & $91-95$ & 5 & 12.5 \\
\hline 6 & $96-100$ & 8 & 20 \\
\hline \multicolumn{2}{|c|}{ Total } & 40 & $100 \%$ \\
\hline
\end{tabular}

The frequency distribution of learning outcomes of experimental class shows that there are 32 pupils who got mark between 81 and 100 . Then there are only 8 pupils got mark between 70 and 80 .

Based on the learning outcomes research data on the experimental group that show $92.5 \%$ of the pupils have got the mark above 75 which is categorized as high and $20 \%$ got the mark between 50 and 75 which is categorized as average, it means that the results of learning Chinese language on subjects who were given treatment in the experimental class is likely to be high.

The result of the uncorrelated sample t-test proves that the cooperative learning method "Make a match" had a significant influence on the mastery of Chinese language vocabulary.

\section{CONCLUSION}

Based on the results of the research that have been calculated, it can be drawn the conclusion that cooperative learning method "Make a match" has a significant influence on the mastery of Chinese language vocabulary of the pupils at Dr. Wahidin Sudirohusodo primary school. This is proved by the significant difference between the post-test mean of control group (64.75) with the post-test mean of experimental group (89.00) on a $5 \%$ significance level.

\section{ACKNOWLEDGMENTS}

The title "ACKNOWLEDGMENTS" should be in all caps and should be placed above the references. The references should be consistent within the article and follow the same style. List all the references with full details.

\section{REFERENCES}

[1] I. d. S. B. Kurniasih, Ragam Pengembangan Model Pembelajaran, Yogyakarta: CV Solusi Distribusi, 2015.

[2] J. Hamdayama, Metodologi Pengajaran, Jakarta: PT Bumi Aksara, 2016.

[3] N. Sudjana, Penilaian Hasil Proses Belajar Mengajar, Bandung: Remaja Rosdakarya, 2005.

[4] A. Suprijono, Cooperative Learning, Yogyakarta: Pustaka Pelajar, 2010.

[5] Rusman, Model-Model Pembelajaran, Jakarta: PT Remaja Rosdakarya, 2012.

[6] S. Nurulhayati, Pembelajaran Kooperatif yang Menggairahkan, Fasilitator, Wahana Informasi dan Komunikasi Pendidikan Taman Kanak-kanak dan Sekolah Dasar, Jakarta: Erlangga, 2005.

[7] Trianto, Mendesain Model Pembelajaran Inovatif Progresif, Jakarta: Kencana Prenada Media Group, 2009.

[8] M. Ibrahim, Model-Model Pembelajaran, Jakarta: Raja Grafindo Persada, 2003.

[9] M. Huda, Model-Model Pengajaran dan Pembelajaran, Yogyakarta: Pustaka Pelajar, 2014.

[10] Suyatno, Menjelajah Pembelajaran Inovatif, Sidoarjo: Masmedia Buana Pusaka, 2009.

[11] A. Lie, Cooperative Learning: Mempraktikkan Cooperative Learning di Ruang-ruang Kelas, Jakarta: Grasindo, 2008.

[12] W. Aziz, Metode dan Model-Model Mengajar IPS, Bandung: Alfabeta, 2007.

[13] Suparto, Tata Bahasa Mandarin Itu Mudah, Jakarta: Puspa Swara, 2003.

[14] J. Semita, Buku Pintar Hanyu Yufa, Yogyakarta: Pustaka Widyatama, 2013. 
[15] S. Kasmadi dan Sunariah, Panduan Modern Penelitian Kuantitatif, Yogyakarta: CV Solusi Distribusi, 2015.

[16] Sugiyono, Statistik Nonparametris Untuk Penelitian, Bandung: CV Alfabeta, 2015.

[17] Sugiyono, Metode Penelitian Pendidikan, Bandung: CV Alfabeta, 2014. 